\title{
History of dermatology and venereology in Serbia - part III/1: Dermatovenereology in Serbia from 1881 - 1918
}

\author{
Bosiljka M. LALEVIĆ-VASIĆ* \\ Institute of Dermatology and Venereology, Clinical Center of Serbia, Belgrade, Serbia \\ *Correspondence: Bosiljka LALEVIĆ-VASIĆ, E-mail: labuba@eunet.rs \\ UDC 616.5(091)"1881/1918” \\ UDC 616.97(091)"1881/1918”
}

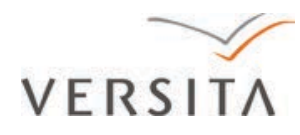

\begin{abstract}
This paper deals with the period from 1881 to 1918, when the following Sanitary Laws were passed: Law on the Organization of the Sanitary Profession and Public Health Care (1881), which implemented measures for protection from venereal diseases, as well as restriction of prostitution; Public Sanitary Fund (1881), with independent budget for health care; Announcement on Free of Charge Treatment of Syphilis (1887). Dermatovenereological Departments were also founded: in the General Public Hospital in Belgrade (1881), and in the General Military Hospital (1909). The Hospital in Knjaževac for Syphilis was reopened (1881), as well as mobile and temporary hospitals for syphilis, and a network of County and Municipality hospitals. The first Serbian dermatovenereologist was Dr. Jevrem Žujović (1860 - 1944), and then Dr. Milorad Savićević (1877 - 1915). Skin and venereal diseases were treated by general practitioners, surgeons, internists and neurologists. Although Dr. Laza Lazarević (1851 - 1890) was not a dermatologist, but a physician and a writer, he published three papers on dermatovenereology, whereas Dr. Milorad Godjevac (1860 - 1933) wrote an important study on endemic syphilis. From 1885 to 1912, organization of dermatovenereology service has significantly improved. Considering the fact that archive documents are often missing, only approximate structure of diseases is specified: in certain monthly reports in Zaječar, out of all the diseased persons, $45 \%$ had skin or venereal diseases, while in Užice the number was $10.5 \%$, which points to different distribution of these diseases. High percentage of dermatovenereology diseases was caused by high frequency of venereal diseases and syphilis. During the war: 1912 - 1918, the military medical service dominated, and in 1917 Prince Alexander Serbian Reserve Hospital was founded in Thessaloniki with a Department for Skin and Venereal Diseases. During this period, work of the Civilian Health Care Service was interrupted, consequently leading to a considerable aggravation of public health.
\end{abstract}

$\mathrm{T}$ his chapter focuses on the period from 1881, when the health care service was legally regulated, to 1918, when the First World War ended. After the Serbian-Bulgarian War (1885), being on the crossroads of Turkish, Austrian and Russian interests for a long time, Serbia entered a period of peace, which lasted about 25 years. Despite the political turmoil in the country, it contributed to progress in every aspect. After this period, the country entered yet another period of war (1912-1918), and the newly established Sanitary Service was shut down. The number of military physicians, insufficient during the peace, became even more apparent during the war, so that civilian doctors were recruited to the army (1), whereas the Sanitary Service was almost completely transformed into a Military Sanitary Service. The consequences were to be distressing and long lasting.

\section{Legislation and organization of the dermatovenereology service}

After the wars which led to the liberation of Serbia (1876 - 1878), things which happened before, occurred again, like in similar situations in the past: the major health problem was the spread of communicable diseases, while their occurrence was associated with historical ups and downs of the country. Apart from venereal diseases, skin diseases spread as well, due to lack of health care, but also due to low life and hygiene standards. Although syphilis remained a dominant health concern, dermatology gained recognition in the frame of general health care.

This period was characterized by establishment of sanitary laws (2), under the authorization of Dr. Vladan Đorđević, the chief of the Sanitary Department 
of the Ministry of Internal Affairs - MIA (1879 1884) (3). In 1881, on his initiative, a Public Sanitary Fund was established, which provided an independent sanitary budget $(2,3)$. Dr. Vladan Đorđević created a Law on the Organization of the Sanitary Profession and Public Health Care (hereinafter: Sanitary Law), which was also adopted in 1881 (4). World experts found it to be one of the best and most contemporary laws in Europe (5).

Of the general Sanitary Law regulations, which applied to all sanitary districts, two were significant for the development of the dermatovenereology service:

- Foundation of district and county hospitals over the whole country during a 10-year-period (6);

- Submission of formal reports on the public health on regular basis $(7,8)$.

Certain law articles concerned organization and development of the dermatovenereology profession:

- Measures for the prevention of multiplication and spread of venereal diseases (9);

- Suppression of wanton and all that provoked it (8).

In the same year, Prostitution Regulations (10) and Regulations of the Hospital Funds gained for Prostitutes were passed. These funds were used for medical checkups and hospital treatment of prostitutes (11).

The Announcement dated 1887, was of utmost importance for the dermatovenereology service. According to the Announcement, treatment of syphilis was free of charge for peasants and workers, regardless of their financial status. In 1895, this privilege was exercised by all patients with sexually transmitted diseases, as well as by railway "guardians" and lowpaid railway staff (12).

The main obstacles for the enforcement of these laws included lack of physicians, lack of specialists and hospitals, and that is why special attention was paid to the above mentioned.

\section{Hospitals}

The Sultan's Edict ("Hatiserif") from 1830 (12), allowed building of hospitals in Serbia, but they were mostly organized in unsuitable buildings for their purpose, whereas their number and equipment were rather deficient. The conclusions of the Medical Board for the investigation of "frenga" in 1846 (see part
II), according to which syphilis was to be treated in hospitals, was extremely important. The new Sanitary Law intended development of a hospital network, as well as reorganization of the existing hospitals, defining eradication of venereal diseases as one of the greatest problems.

By the Sanitary Law, the previous County and Belgrade City Hospital was transformed into the General Public Hospital (GPH), with five departments, one of them being the Department for Skin Diseases and Syphilis. It was the first dermatovenereology department in Serbia, and it had separate sections for male and female patients $(5,6)$.

A Department for Skin and Venereal Diseases was also founded in the frame of the General Military Hospital (GMH), after a new hospital was built in the western part of Vračar, in 1909. The acting chief of the Department was Captain First Class, Dr. Milutin Pop Jovanović (13).

The Knjaževac Hospital for Syphilis, burnt down in 1876 in the Serbian - Turkish war (see part II), was reopened in 1881, in a private residence. It remained there for ten years to come, but after that it was moved into a restored, old hospital (14).

The County and District General Hospitals also represented important centers for the treatment of skin and venereal diseases.

Apart from these, in regions with a great number of patients suffering from syphilis, in 1882 a new way of treatment was organized: two mobile hospitals, which were active till 1885 , with some interruptions. The treatment took place at a person's residence, under the supervision of a doctor, and it lasted for months, even after the end of treatment $(12,14)$.

For the same reasons, in 1894, three temporary hospitals for syphilis were founded: in Vitkovo, Krupanj and Soko Banja, as well as a Hospital for the Treatment of Syphilis in Boljevac (15).

These kinds of hospitals were possibly organized in other areas with a great number of diseased.

This extraordinarily long period of peace allowed good organization of an antivenereal service, decreasing the number of patients with syphilis. In 1912, a war period started, and lasted till 1918. At that time, the total number of physicians in Serbia was 370 , out of which 296 were recruited into the 
army, whereas 57 physicians capable of work were left behind (16). It affected the public health a great deal, causing spread of venereal and skin diseases once again. During the war period, a military sanitary network was reorganized, and on March 16, 1917, the "Prince Alexander Serbian Reserve Hospital" (PASRH) was founded in Thessaloniki. It was the Central Military Hospital of the Serbian Army in exile; it included a Department for Skin and Venereal Diseases, and its chief was Major Dr. Dušan Kopša (17).

In this way, organization of dermatovenereology service gained its position both in peace and in war. However, the discontinuity, which goes hand-in-hand with the Serbian history through centuries, this time, also stopped the progress of the sanitary service.

\section{Physicians}

One of the reasons which made enforcement of the Sanitary Law extremely difficult was lack of physicians in Serbia: in 1895 there were 150, in 1900 there were 200 , and in 1908 there were 288 physicians. Before the outbreak of the Balkan Wars, in 1912, there were 370 physicians in Serbia. Although the law required medical specialists for some positions, with the exception of surgeons (there were 30 surgeons at the end of the 19 th and at the beginning of the 20th century) (3), they were extremely scarce. Until the twentieth years of the 20th century, dermatovenereologists were really rare. That is why implementation of the Sanitary Law took a long time.

Dr. Jevrem Žujović (1860 - 1944) was the first educated Serbian dermatovenereologist (Figure 1). He studied medicine in France, and specialized in dermatovenereology at the St. Louis Hospital in Paris with Professor A. Fournier, a specialist in syphilisology of worldwide reputation (18). He became a Head of the Department of Skin Diseases and Syphilis at the GPH in 1889 (19). He implemented modern dermatology doctrine in the whole country, organized struggle against syphilis and surveillance of prostitution, and also studied leprosy. He introduced arsenic into the treatment of syphilis, while in 1909 he organized a laboratory for the Wassermann reaction test and microscopic detection of Treponema pallidum in skin lesions (20). He translated a book by A. Fournier: "Syphilis and Marriage". Together with M. Jovanović-

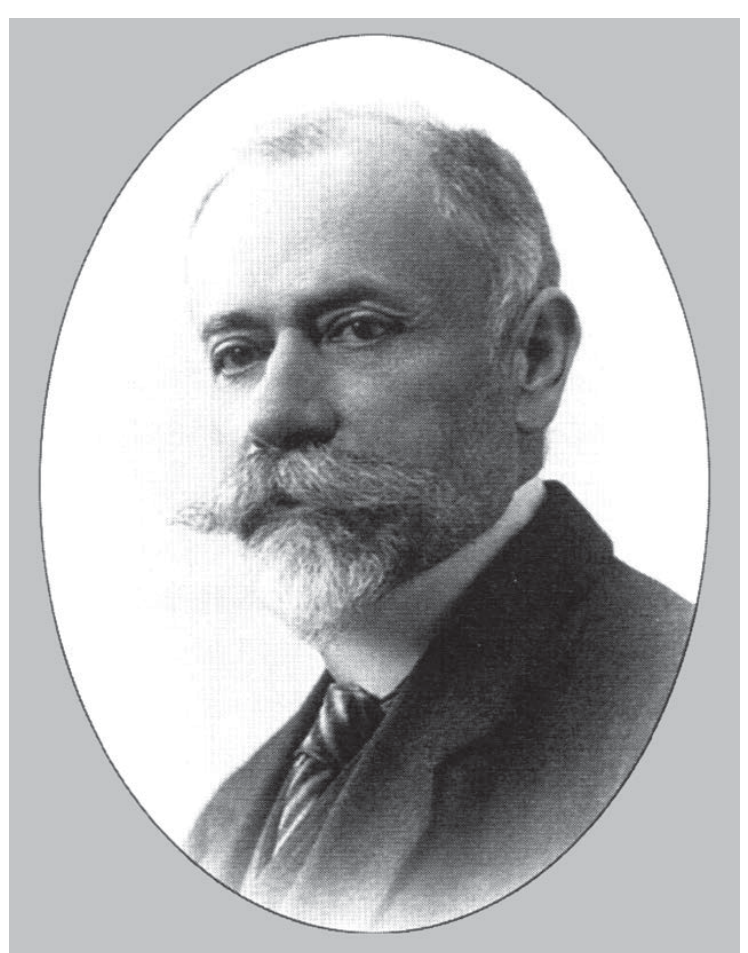

Figure 1. Jevrem M. Žujović

Batut, he wrote "Instructions on Syphilis" according to the decision of the Serbian Medical Society (21). He was also the first President of the Yugoslav Dermatology Association.

Dr. Milorad Savićević (1877 - 1915) was a Vienna medical student who specialized in dermatovenereology with Professor Dr. E. Finger. From 1908, he was a secondary physician at the GPH. He died from spotted typhus in 1915 (21). During his short life he had built up an enviable bibliography. Apart from several professional and scientific papers, he wrote the following books: "Venereal Diseases", "Venereal Diseases and their Effects on Marital Life and on the Offspring", "Prostitutes", "Who May get Married", "Sexual Life and its Consequences", "Physicians and the Audience". "The Beauty of the Body, its Care and Cosmetology" is probably our first book in cosmetology. He also translated several books on syphilis (22). His early death was a great loss for Serbian dermatovenereology.

Dr. Filip Tajsić, a Sanitary Colonel, was a Vienna student; he specialized in dermatovenereology for 11 months in Paris, but he never practiced it. After his return to the country, he joined the army where he 
mostly held leading position in the Military Medicine (21).

The above mentioned doctors, Milutin PopJovanović (GMH) and Dušan Kopša (PAH) were educated dermatovenereologists as well. The former one died in 1914, from sepsis (23).

According to the documents and reports of the Serbian Medical Society, as well as of the Serbian Archive for General Medicine, skin and venereal diseases were mostly treated by general practitioners, surgeons, internists and neurologists. Some of them attracted special attention.

Dr. Laza Lazarević, (1851 - 1890), was a writer, creator of the genre of realistic story, "our first clinician, first scientist and first philosopher-physician" (21). During his short life he left his mark in dermatology as well. He graduated from medicine in Berlin in 1879, with a thesis entitled "Effects of Mercury on Rabbit Tissues" (24). He also published the following papers: "A Contribution on Latent Syphilis" (25); "Two Rare Cases of Erythema Nodosum" (26); "Exanthem Variola - Syphilitic Exanthem" (27).

Dr. Milorad Godevac (1860 - 1933), was a physician in Belgrade municipality (21). He spent three years in Knjaževac $(1890$ - 1893) on a "special mission" by the order of the MIA, in order to study endemic syphilis and suggest solutions for its eradication. After this mission, he published a monograph which remained a valuable document on all circumstances in the region (28).

In this period, Vojislav Mihailovic (Graz, 1904), (29), Ivan Marković (Vienna, 1914), and Miloš Đorić (Nancy, 1914) (30), were among our students of medicine who later became eminent dermatovenereologists.

(To be continued in the next issue)

\section{References:}

1. Stanojević Vl. Rad našeg saniteta u Balkanskom ratu 1912. i 1913. godine [Our sanitary service during the Balkan wars, in 1912 and 1913]. U: Gvozdenović N, Stanojević L, urednici. 700 godina medicine u Srba [700 years of Medicine in Serbs]; Beograd: SANU; 1972. str. 218-26.

2. Milovanović V, urednik. Medicinski godišnjak Kraljevine Jugoslavije. Ministarstvo socijalne politike i narodnog zdravlja br. 15080 [Medical almanac of the Kingdom of Yugoslavia. Ministry of social policy and public health, No: 15080].
Beograd: Jugoreklam; 1933.

3. Đokić D, Dovijanić P. Osamdeset godina u službi zdravlja naroda. 2. izd. [Eighty years of the public health service, $2 \mathrm{nd}$ ed]. Beograd: Institut za zaštitu zdravlja Srbije "dr Milan Jovanović Batut"; 2000

4. Garašanin M. Raspis svim Načalstvima, upravi varoši Beograda i gospodinu Ministru finansija [Circular announcement to all executives, city administration of Belgrade and mr. ministry of finance]. Nar Zdrav 1882;1:13.

5. Gjorgjewitj V. Entwicklung der oeffentlichen Gesundheitspflege im Serbischen Königreiche von XII Jahrhundert an bis 1883. Berlin: Max Pasch; 1883.

6. Zakon o uređenju sanitetske struke i o čuvanju narodnog zdravlja [Law on the organization of the sanitary profession and public health care]. Srp Novine. 1881 Apr.10;49(80).

7. Zakon o uređenju sanitetske struke i o čuvanju narodnog zdravlja [Law on the organization of the sanitary profession and public health care]. Srp Novine. 1881 Apr. 6;49(76).

8. Zakon o uređenju sanitetske struke i o čuvanju narodnog zdravlja [Law on the organization of the sanitary profession and public health care]. Srp Novine 1881 Apr. 4;49(75).

9. Zakon o uređenju sanitetske struke i o čuvanju narodnog zdravlja [Law on the organization of the sanitary profession and public health care]. Srp Novine 1881 Apr. 9;49(79).

10. Garašanin M. Pravila o regulisanju prostitucije [Prostitution regulations]. Nar Zdrav 1882;1:10-3..

11. Pravila o rukovanju sa bolničkom kasom prostitucijanih [Regulations of the hospital funds for prostitutes]. Nar Zdrav 1881;1(31):385-6.

12. Mihajlović V. Istorija polnih bolesti u Srbiji do 1912. godine [The history of venereal diseases in Serbia up to 1912]. Beograd: Štamparija Centralnog higijenskog zavoda 1931;7.

13. Stojiljković MP, Zeljković J, Tadić V. Iz istorije Vojnomedicinske akademije: I Vojne bolnice u Beogradu od 1836. do 1838. godine [Out of the history of the military medical academy: the first military hospitals in Belgrade, from 1836 to 1838]. Vojnosanit Pregl 2002;59(3):329-33.

14. Ivanović-Šakabenta D. 150 godina bolnice u Knjaževcu [150th anniversary of the Knjaževac hospital]. Knjaževac: Zdravstveni centar; 2001.

15. Kalendar sa šematizmom Knjaževstva Srbije za godinu 1894. [A schematic calendar of the Serbian principality for 1894]. Beograd: Državna štamparija; 1894.

16. Ignjatović M. Istorija vojne hirurgije u Srbiji (do Drugog svetskog rata) [The History of the military surgery in Serbia (till the second world war)]. U: Čolović RB, urednik. Hronika hirurgije u Srbiji (Annals of surgery in Serbia). Beograd: Prosveta; 2002. str.143-98.

17. Nedok AS. Reorganizacija vojnog saniteta u 1916. godini [Reorganization of the military sanitary service in 1916]. U: Nedok AS, Dimitrijević B, urednici. Srpski vojni sanitet u 1916. godini [The Serbian military sanitary service in 1916]. Beograd: Akademija medicinskih nauka SLD; 2007. str. 11-42.

18. Žujović J. Curriculum vitae. Arhiv Muzeja SLD.

19. Kalendar sa šematizmom Knjaževstva Srbije za godinu 1889.

[A schematic calendar of the Serbian principality for 1889]. 
Beograd: Državna štamparija; 1889.

20. Žujović J. Rapport de la Société de la Croix-Rouge des Serbes, Croates et Slovènes à la conférence régionale de l'Europe orientale sur les maladies vénériennes. Décembre 1921, Prague. (Rukopis). Beograd: Arhiv Muzeja SLD ; 1921.

21. Stanojević V. Likovi i dela istaknutih lekara od osnivanja Srpskog lekarskog društva do danas [Lives and work of outstanding physicians from the foundation of the Serbian medical society till present]. U: Đurić D, i dr.urednici. Srpsko lekarsko društvo 1872-1972: spomenica. Beograd: SLD; 1972. str.159-234.

22. Stanojević S, urednik. Savićević dr Milorad. U: Narodna enciklopedija srpsko-hrvatsko-slovenačka [National encyclopedia of Serbo-Croats and Slovenes]. Zagreb: Bibliografski zavod d.d; 1928.

23. Nedok AS. Personalna istorija srpskog vojnog saniteta [Personal history of the Serbian military sanitary service]. U rukopisu (A manuscript).

24. Lešić A, Bumbaširević M. Dr Laza K. Lazarević - književnik i lekar (1851-1890) [Dr. Laza K. Lazarević, a writer and a physician]. Srp Arh Celok Lek 2005;133(1-2):106-9.

25. Lazarević LK. Jedan prilog za latentnu sifilidu [A contribution on latent syphilis]. Srp Arh Celok Lek. 1881; 2-4.
26. Lazarević LK. Dva retka slučaja erythema nodosum [Two rare cases of erythema nodosum]. Srp Arh Celok Lek 1883:97103.

27. Lazarević LK. Egzantem-variola-sifilisni egzantem: saopštenje na 13. redovnom sastanku SLD [Exanthem - variola - syphilitic exanthem: announcement]. Beograd: SLD; 1887.

28. Gođevac M. Sifilis u Timočkoj krajini. Način kako da se stane na put širenju te zaraze [Syphilis in the Timok region. modalities for stopping the spread of the infection]. Beograd: Parna radikalna štamparija; 1893.

29. Kalendar sa šematizmom Knjaževstva Srbije za godinu 1904. [A schematic calendar of the Serbian principality for 1904]. Beograd: Državna štamparija; 1904.

30. Kalendar sa šematizmom Knjaževstva Srbije za godinu1914. [A schematic calendar of the Serbian principality for 1914]. Beograd: Državna štamparija; 1914.

\section{Abbreviations}

MIA: Ministry of Internal Affairs

GPH: General Public Hospital

GMH: General Military Hospital

PASRH: Prince Alexander Serbian Reserve Hospital 